\title{
First record of the genus Myllaena Erichson from Brazil, description of a new species and annotated catalog of Myllaena species from the Neotropical region (Coleoptera, Staphylinidae, Aleocharinae) ${ }^{1}$
}

\author{
Edilson Caron² \& Jan Klimaszewski ${ }^{3}$
}

\begin{abstract}
${ }^{1}$ Contribution $\mathrm{n}^{\circ} .1733$ of the Departamento de Zoologia, Universidade Federal do Paraná, Brazil.
${ }^{2}$ Laboratório de Sistemática e Bioecologia de Coleoptera (Insecta), Departamento de Zoologia, Universidade Federal do Paraná, Caixa Postal 19020, 81531-980 Curitiba-PR, Brazil. CNPq fellowship. caron@ufpr.br

${ }^{3}$ Natural Resources Canada, Canadian Forest Service, Laurentian Forestry Centre, 1055 du PEPS, P.O. Box 10380, Stn. Sainte-Foy Québec, QC, Canada G1V 4C7. jklimaszewski@cfl.forestry.ca
\end{abstract}

\begin{abstract}
First record of the genus Myllaena Erichson from Brazil, description of a new species and annotated catalog of Myllaena species from the Neotropical region (Coleoptera, Staphylinidae, Aleocharinae). The genus Myllaena Erichson, 1837, of the tribe Myllaenini Ganglbauer, 1895, is recorded from Brazil for the first time. A new species, Myllaena brasiliensis sp. nov., is described and illustrated; it is closely related to the insomnis species group, described from the Nearctic region. A short diagnosis of the genus and an annotated catalog of Myllaena species from the Neotropical region are also provided.
\end{abstract}

KEYWORDS. Brazil; distribution; rove beetles; taxonomy.

\begin{abstract}
RESUMO. Primeiro registro do gênero Myllaena Erichson no Brasil, descrição de uma nova espécie e catálogo comentado das espécies de Myllaena da região Neotropical (Coleoptera, Staphylinidae, Aleocharinae). O gênero Myllaena Erichson, 1837, da tribo Myllaenini Ganglbauer, 1895, é registrado pela primeira vez no Brasil. Uma nova espécie, Myllaena brasiliensis sp. nov., é descrita e ilustrada; esta espécie é proximamente relacionada ao grupo de espécies insomnis, descritas da região Neártica. Uma breve diagnose do gênero e um catálogo comentado das espécies de Myllaena da região Neotropical são também fornecidos.
\end{abstract}

PALAVRAS-CHAVE. Brasil; distribuição; estafilinídeos; taxonomia.

The tribe Myllaenini Ganglbauer, 1895 is a monophyletic taxon embracing a group of species whose position appears to be solidly established within the 'higher' Aleocharinae (Ahn \& Ashe 2004; Ashe 2005). Myllaena Erichson, 1837 is a small genus with some 205 species worldwide (Newton \& Thayer 2005), and 30 species recorded from the Neotropical region (Newton et al. 2005). The species occur in riparian habitats predominantly associated with edges of streams, rivers and lakes (Klimaszewski 1982).

In the present paper, a new species of Myllaena is described and illustrated and the genus is for the first time recorded in Brazil. A short diagnosis of the genus and an annotated catalog of Myllaena species from the Neotropical region are also provided.

\section{MATERIAL AND METHODS}

Dried specimens were first macerated in boiling water for five minutes and then cleared in boiling $10 \% \mathrm{KOH}$ for two minutes. The micro dissections were carried out under the stereoscopic microscope, Zeiss Stemi SV6, and the drawings were made using the same equipment and Zeiss Standard 20 optical microscope with attached drawing tube. Photographs were taken using a stereoscopic microscope Leica MZ 16 with a Leica DFC 500 digital camera. The images were captured with computer software IM 50 (Image Manager) and combined using the image processing software Auto-Montage Pro 5.03.0040. The final versions of drawings and photographs were prepared using Adobe Photoshop software, version 7.0.

Measurements were done using the micrometric ocular in the stereoscopic microscope Wild M5. The following abbreviations were used: BL, body length (from anterior margin of head to posterior margin of tergite VIII); BW, body width (across humeral region); PL, pronotum length (maximum); PW, pronotum width (maximum); EL, elytra length (maximum).

The terminology used in the text is adopted from Blackwelder (1936) and Klimaszewski (1982).

Specimens are deposited in the Coleção de Entomologia Pe. J.S. Moure, Departamento de Zoologia, Universidade Federal do Paraná, Curitiba, Brazil (DZUP); Museu Nacional do Rio de Janeiro, Rio de Janeiro, Brazil (MNRJ); Museu de Zoologia, Universidade de São Paulo, São Paulo, Brazil (MZSP); Museu de Ciências Naturais da Fundação ZooBotânica do Rio Grande do Sul, Porto Alegre, Brazil (MCNZ); Field Museum of Natural History, Chicago, United States (FMNH); and the Insectarium R. Martineau, Laurentian Forestry Centre, Quebec, Canada (LFC). 


\section{RESULTS ANDDISCUSSION}

Myllaena Erichson, 1837

(Figs. 1-2, 4-8, 10, 13)

Myllaena Erichson 1837: 382. For review of literature see Klimaszewski (1982).

Type species: Aleochara dubia Gravenhorst 1806: 173, by subsequent designation.

Diagnosis. Body fusiform, abdomen tapering from base to apex (Fig. 1), flattened and bearing long macrosetae, integument with short and dense microsetae adhering to the body surface. Tarsal formula 4-4-5. Head hypognathous. Labrum transverse (Fig. 4), anterior margin slightly emarginated. Epipharynx with sensory pores asymmetrically distributed, and with series of small denticles in lateral region (Fig. 5). Mandibles symmetrical, long with curved apex, with smooth inner margin and well developed prostheca (Fig. 6). Maxilla slender and elongate, lacinia and galea of the same length, galea narrower than lacinia, with series of subapical bristles, maxillary palpus with four articles, article 1st vestigial, 2nd the longest, 3rd ovate and 4th medially divided into pseudosegments (Fig. 7). Glossae extremely elongate (Fig. 8). Mentum trapezoidal, anterior angles prolonged into spinose processes (Fig. 8). Pronotal hypomera not visible in lateral view (Fig. 2). Procoxae conical. Prosternum transverse. Mesosternal process about half length of mesocoxae (Fig. 10), mesocoxae contiguous, mesocoxal cavities not margined posteriorly. Metacoxae flattened and transverse. Tergite IX in both sexes separated by tergite $\mathrm{X}$ (Fig. 13). Tergite $X$ deeply emarginated medially (Fig. 13).

\section{Myllaena brasiliensis sp. nov.}

(Figs. 1-16)

Type material. Holotype (male): BRAZIL, Rio Grande do Sul, Rio Grande, Praia do Cassino, 20-I-1993, Gianuca col. (DZUP). Paratypes: same locality and collector, 06-I-1993 (1 male and 2 sex undetermined, FMNH), 20-I-1993 (2 sex undetermined, DZUP), 27-I1993 (2 males, 1 female and 1 sex undetermined, DZUP; 2 sex undetermined, MCNZ; 1 female and 1 sex undetermined, MZSP; 1 female and 1 sex undetermined, MNRJ; 1 male, 1 female and 3 sex undetermined, LFC), 10-II-1993 (1 male and 2 females, DZUP).

\section{Description. BL: 1.40-1.74 mm; BW: 0.56-0.64 mm.}

Head and abdomen dark brown (segments III-VI); antennae, mouthparts, pronotum, elytra, legs and apex of abdomen (segment VII-VIII) light brown (Figs. 1, 2). Head about as long as wide and without differentiated neck. Eyes large, covering most of the visible lateral region of head. Antennae reaching the base of elytra, scape broad and slightly elongate, pedicel the longest, articles 3-10 elongate but gradually decreasing in length toward antennal apex, the last article somewhat clavate (Fig. 3). Mentum with two short anterior teeth medially (Fig. 8). Pronotum convex, wider than long (Fig. 9) (PW/PL: 1.44), widest behind the middle, posterior margin sinuate. Elytra wider than long (BW/EL: 1.54). Hind wings fully developed. Abdomen with numerous prominent macrosetae. MALE. Tergite VIII elongate, broadly rounded apically and slightly pointed

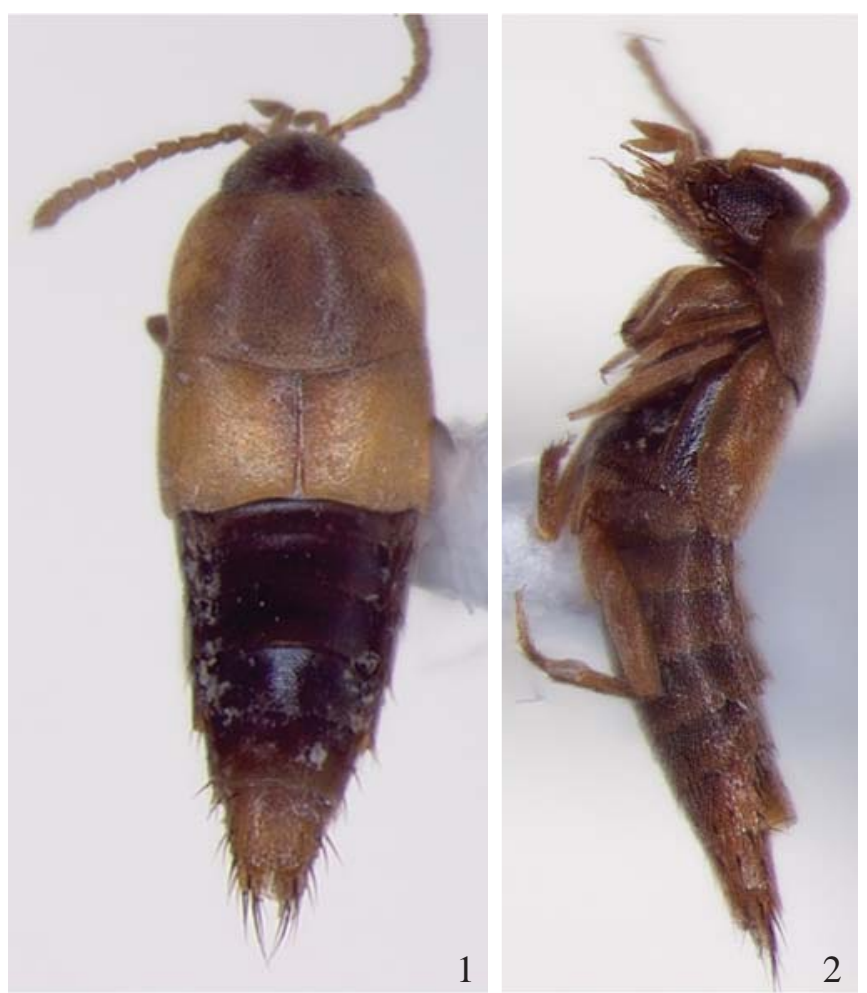

Figs. 1-2. Myllaena brasiliensis sp. nov. 1. dorsal view; 2. lateral view.

medially (Fig. 11), with four pairs of prominent setae distributed latero-posteriorly. Sternite VIII elongate and rounded posteriorly with four pairs of prominent setae distributed lateroposteriorly (Fig. 12). Median lobe of aedeagus approximately round, moderately sized bulbus, and narrowly elongate tubus with truncate apex (Fig. 14). Internal sac with flagellum as long as the median lobe (Figs. 14, 15). Paramere as illustrated (Fig. 14). FEMALE. Sternite VIII and tergite $X$ similar to those of male. Spermatheca with pitcher-shaped tubular capsule, median invagination moderately deep, stem long with multiple coils (Fig. 16).

Etymology. The specific name derives from Brasil, the name of the country where the type series was discovered.

Distribution. Southeastern Brazil (Rio Grande do Sul: Rio Grande: Praia do Cassino).

Remarks. The shape of the aedeagus (Figs. 14, 15) and the shape of the spermatheca (Fig. 16) of Myllaena brasiliensis sp. nov. are similar to those of the insomnis species group described from the Nearctic region (M. audax Casey, 1911; $M$. brevicollis Casey, 1911; M. decreta Casey, 1911; M. hopkinton Klimaszewski, 1982; M. insomnis Casey, 1911; and M. magnolia Klimaszewski, 1982). The morphology of the median lobe of the aedeagus and the multiply coiled stem of the spermatheca are matching characteristics of the insomnis group and therefore we regard our newly described species as affiliated to this group.

Many species of Myllaena from the Neotropical region are poorly diagnosed and illustrated. This raises the need of revising all species of this group from the entire region. We 

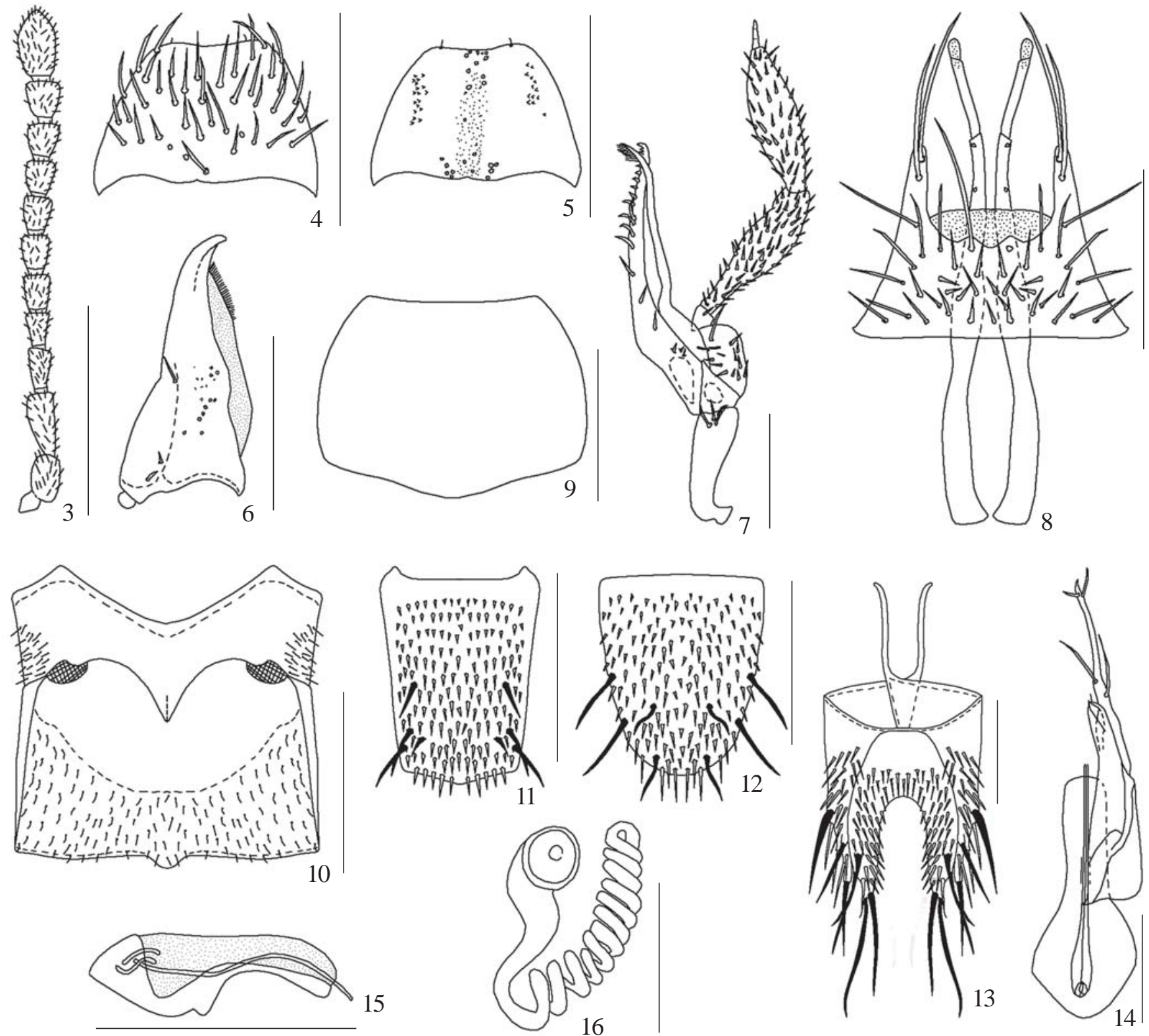

Figs. 3-16. Myllaena brasiliensis sp. nov. 3. antenna; 4. labrum, dorsal view; 5. epipharynx, ventral view; 6. left mandible, dorsal view; 7. maxilla, dorsal view; 8. labium, ventral view; 9. pronotum, dorsal view, setae removed; 10. meso-metathorax, ventral view; 11. tergite VIII, male, dorsal view; 12. sternite VIII, male, ventral view; 13. tergite IX-X, male, dorsal view; 14. aedeagus, ventral view, left paramere removed; 15. median lobe, lateral view; 16. spermatheca. Scale: Figs. 3, 9-12, $15=0.25 \mathrm{~mm} ; 4-8,13,14,16=0.15 \mathrm{~mm}$.

did not hesitate to describe $M$. brasiliensis as a new species because it is the only known species of this genus from all of Brazil.

\section{Annotated catalog of species of Myllaena Erichson, 1837 from Neotropical region}

\section{Myllaena Erichson, 1837}

Myllaena Erichson 1837: 382. For review of literature see Klimaszewski (1982).
Type species: Aleochara dubia Gravenhorst 1806: 173, by subsequent designation.

\section{Myllaena araucaniensis Pace, 1987}

Myllaena araucaniensis Pace 1987b: 470-472 [original description, illustrated; comparison with $M$. dilutipes Fairmaire \& Germain, 1861 and M. parvicollis Kraatz, 1859]. Pace 1999: 121 [new records from Chile]: 140, 142 [comparison with M. gonzalezi Pace, 1999]. Type locality: "Araucanie" (Pace 1987b).

Distribution: Chile (Pace 1987b). 


\section{Myllaena arcana Casey, 1911}

Myllaena arcana Casey 1911: 239 [original description]. Notman 1920: 708 [characters in key]. Bernhauer \& Scheerpeltz 1926: 508 [in world catalog, as synonym of M. minuta (Gravenhorst, 1806)]. Scheerpeltz 1934: 1529 [in world catalog, as synonym of $M$. minuta (Gravenhorst, 1806)]. Blackwelder 1944: 153 [in checklist from Neotropical region, as synonym of M. minuta (Gravenhorst, 1806)]. Moore \& Legner 1975: 454 [in Nearctic catalog, as synonym of M. minuta (Gravenhorst, 1806)]. Klimaszewski 1982: 220-221 [redescription, as valid species; lectotype designated]: 183 [in checklist from Nearctic region, as valid species]: 186 [geographic distribution]: 191 [characters in key]: 216 [in cuneata species group]: 217 [distribution map]: 193, 222-223, 240 [illustrations]. Klimaszewski \& Génier 1986: 35 [new records from USA]. Klimaszewski \& Frank 1992: 400-401 [new records from USA]. Pace 1997: 102 [characters; comparison with M. cornelli Pace, 1997]. Navarrete-Heredia et al. 2002: 191 [in checklist from Mexico].

Type locality: "USA, Iowa, Cedar Rapids" (Klimaszewski 1982).

Myllaena immunda Casey 1911: 240 [original description]. Notman 1920: 709 [characters in key]. Bernhauer \& Scheerpeltz 1926: 507 [in world catalog, as synonym of $M$. infuscata Kraatz, 1853]. Scheerpeltz 1934: 1528 [in world catalog, as synonym of $M$. infuscata Kraatz, 1853]. Moore \& Legner 1975: 454 [in Nearctic catalog, as synonym of $M$. infuscata Kraatz, 1853]. Klimaszewski 1982: 220 [lectotype designated, as synonym of M. arcana Casey, 1911]: 183 [in checklist from Nearctic region, as synonym of $M$. arcana Casey, 1911].

Type locality: "Canada, Ontario, Ottawa" (Klimaszewski 1982).

Distribution: Canada; USA; Mexico (Klimaszewski 1982).

\section{Myllaena celerrima Cameron, 1922}

Myllaena celerrima Cameron 1922: 650 [original description; comparison with M. mollis Sharp, 1883]: 651 [comparison with M. diversicornis Cameron, 1922]. Bernhauer \& Scheerpeltz 1926: 505 [in world catalog]. Blackwelder 1943: 534 [citation]: 579 [in checklist from West Indies]. Blackwelder 1944: 153 [in checklist from Neotropical region].

Type locality: "Grenada, St. Vincent" (Cameron 1922).

Distribution: Grenada; Saint Vincent Island (Saint Vincent and the Grenadine) (Cameron 1922).

\section{Myllaena chibcha Pace, 1996}

Myllaena chibcha Pace 1996: 399-400 [original description; comparison with $M$. insipiens Casey, 1911]: 401 [illustrations]. Newton et al. 2005: 27 [in checklist from Colombia].

Type locality: "Kolumbien, Punta de Betin, Sta. Marta" (Pace 1996).

Distribution: Colombia (Pace 1996).

\section{Myllaena coyhaiquensis Pace, 1999}

Myllaena coyhaiquensis Pace 1999: 140-141 [original description, illustrated; comparison with M. leleupi Pace, 1985]: 121 [citation]. Type locality: "S Chile, Umg. Coyhaique" (Pace 1999).

Myllaena coyhaiquensi Pace 1999: 140 [misspelling].

Distribution: Chile (Pace 1999).

\section{Myllaena curticornis Cameron, 1922}

Myllaena curticornis Cameron 1922: 651 [original description; comparison with $M$. diversicornis Cameron, 1922]. Bernhauer \& Scheerpeltz 1926: 505 [in world catalog]. Blackwelder 1943: 534 [citation]: 579 [in checklist from West Indies]. Blackwelder 1944: 153 [in checklist from Neotropical region].

Type locality: "Grenada" (Cameron 1922).

Distribution: Grenada (Cameron 1922).

\section{Myllaena debilicornis Sharp, 1883}

Myllaena debilicornis Sharp 1883: 286 [original description; comparison with M. mollis Sharp, 1883, M. fragilis Sharp, 1883 and M. intermedia Erichson, 1837]. Bernhauer \& Scheerpeltz 1926: 505 [in world catalog]. Blackwelder 1944: 153 [in checklist from Neotropical region].

Type locality: "Guatemala, San Gerónimo" (Sharp 1883).

Distribution: Guatemala (Sharp 1883).

\section{Myllaena difficilis Cameron, 1922}

Myllaena difficilis Cameron 1922: 651 [original description; comparison with $M$. diversicornis Cameron, 1922]. Bernhauer \& Scheerpeltz 1926: 505 [in world catalog]. Blackwelder 1943: 534 [citation]: 579 [in checklist from West Indies]. Blackwelder 1944: 153 [in checklist from Neotropical region].

Type locality: "Jamaica" (Cameron 1922).

Distribution: Jamaica (Cameron 1922).

\section{Myllaena dilutipes Fairmaire \& Germain, 1861}

Myllaena dilutipes Fairmaire \& Germain 1861: 424 [original description; comparison with M. glauca Aubé, 1850]. Fauvel 1864: 124 [citation, as synonym of $M$. parvicollis Kraatz, 1859]. Lynch 1884: 99 [citation, as synonym of $M$. parvicollis Kraatz, 1859]. Bernhauer \& Scheerpeltz 1926: 508 [in world catalog, as synonym of $M$. parvicollis Kraatz, 1859]. Blackwelder 1944: 153 [in checklist from Neotropical region, as synonym of $M$. parvicollis Kraatz, 1859]. Coiffait \& Saiz 1967: 61-63 [redescription, as valid species; illustrated]: 60-61 [characters in key]: 63 [comparison with $M$. ferrugata Fairmaire \& Germain, 1861 and M. parvicollis Kraatz, 1859]: 64 [comparison with $M$. extracta Coiffait \& Saiz, 1967]. Pace 1987b: 472 [comparison with M. araucaniensis Pace, 1987b]. Pace 1999: 121 [citation, as synonym of M. parvicollis Kraatz, 1859]. Type locality: "Quillota" (Fairmaire \& Germain 1861).

Distribution: Chile (Fairmaire \& Germain 1861).

\section{Myllaena diversicornis Cameron, 1922}

Myllaena diversicornis Cameron 1922: 650-651 [original description; comparison with $M$. celerrima Cameron, 1922, M. curticornis Cameron, 1922 and M. difficilis Cameron, 1922]. Bernhauer \& Scheerpeltz 1926: 505 [in world catalog]; Blackwelder 1943: 534 [citation]: 579 [in checklist from West Indies]. Blackwelder 1944: 153 [in checklist from Neotropical region]. Pace 1987a: 188 [comparison with M. guadalupensis Pace, 1987a].

Type locality: "Grenada, St. Vincent" (Cameron 1922).

Distribution: Grenada; Saint Vincent Island (Saint Vincent and the Grenadines) (Cameron 1922).

\section{Myllaena extracta Coiffait \& Saiz, 1967}

Myllaena extracta Coiffait \& Saiz 1967: 63-64 [original description; comparison with $M$. dilutipes Fairmaire \& Germain, 1861]: 61 [characters in key].

Type locality: without locality. Note: "Holotype: une femelle du Museo Nacional de Chile, sans date ni localité" in Coiffait \& Saiz 1967, page 63 . 
Distribution: Chile (?) (Coiffait \& Saiz 1967).

\section{Myllaena ferrugata Fairmaire \& Germain, 1861}

Myllaena ferrugata Fairmaire \& Germain 1861: 424-425 [original description]. Lynch 1884: 99 [citation, as synonym of M. parvicollis Kraatz, 1859]. Bernhauer \& Scheerpeltz 1926: 508 [in world catalog, as synonym of $M$. parvicollis Kraatz, 1859]. Blackwelder 1944: 153 [in checklist from Neotropical region, as synonym of $M$. parvicollis Kraatz, 1859]. Coiffait \& Saiz 1967: 63 [redescription, as valid species; comparison with $M$. dilutipes Fairmaire \& Germain, 1861]: 62 [illustration]: 60-61 [characters in key].

Type locality: "Quillota" (Fairmaire \& Germain 1861).

Distribution: Chile (Fairmaire \& Germain 1861).

\section{Myllaena fragilis Sharp, 1883}

Myllaena fragilis Sharp 1883: 286 [original description; comparison with M. intermedia Erichson, 1837, M. mollis Sharp, 1883 and M. debilicornis Sharp, 1883]. Bernhauer \& Scheerpeltz 1926: 506 [in world catalog]. Blackwelder 1943: 534-535 [new record from Saint Lucia]: 579 [in checklist from West Indies]. Blackwelder 1944: 153 [in checklist from Neotropical region].

Type locality: "Guatemala, San Gerónimo" (Sharp 1883).

Distribution: Guatemala (Sharp 1883); Saint Lucia (Blackwelder 1943).

\section{Myllaena gonzalezi Pace, 1999}

Myllaena gonzalezi Pace 1999: 140-142 [original description, illustrated; comparison with M. araucaniensis Pace, 1987b]: 121 [citation]. Type locality: "Chile, Algarrobo" (Pace 1999).

Distribution: Chile (Pace 1999).

\section{Myllaena granulata Cameron, 1922}

Myllaena granulata Cameron 1922: 652 [original description; comparison with $M$. mollis Sharp, 1883]. Bernhauer \& Scheerpeltz 1926: 507 [in world catalog (error: Cameron 1922: 651)]. Blackwelder 1943: 535 [citation]: 579 [in checklist from West Indies]. Blackwelder 1944: 153 [in checklist from Neotropical region (error: Cameron 1922: 651)].

Type locality: "Jamaica" (Cameron 1922).

Distribution: Jamaica (Cameron 1922).

\section{Myllaena guadalupensis Pace, 1987}

Myllaena guadalupensis Pace 1987a: 187-188 [original description; comparison with $M$. potawatomi Klimaszewski, 1982 (error: $M$. potawatomi Klimaszewski, 1984) and M. diversicornis Cameron, 1922]: 197 [illustrations].

Type locality: "Guadeloupe" (Pace 1987a).

Distribution: Guadeloupe (Pace 1987a).

\section{Myllaena hopi Klimaszewski, 1982}

Myllaena hopi Klimaszewski 1982: 206-208 [original description, illustrated]: 184 [in checklist from Nearctic region]: 186 [geographic distribution]: 187, 193, 240 [illustrations]: 191 [characters in key]: 192 [in potawatomi species group]: 202 [distribution map]. Navarrete-Heredia et al. 2002: 191 [in checklist from Mexico].

Type locality: "USA, [Arizona] Cochise Co., Chiric Mts., Herb Martyr Cmp., 6 mi SW Portal, 6000 ft" (Klimaszewski 1982).
Distribution: USA; Mexico (Klimaszewski 1982).

\section{Myllaena indefatigabilis Cameron, 1922}

Myllaena indefatigabilis Cameron 1922: 651 [original description; comparison with $M$. infuscata Kraatz, 1853 and M. obscura Cameron, 1922]. Bernhauer \& Scheerpeltz 1926: 507 [in world catalog (error: Cameron 1922: 650)]. Blackwelder 1943: 535 [citation]: 579 [in checklist from West Indies]. Blackwelder 1944: 153 [in checklist from Neotropical region (error: Cameron 1922: 650)].

Type locality: "St. Lucia" (Cameron 1922).

Distribution: Saint Lucia (Cameron 1922).

\section{Myllaena leleupi Pace, 1985}

Myllaena leleupi Pace 1985: 450 [original description; comparison with M. cuneata Notman, 1920]: 451 [illustrations]. Klimaszewski \& Peck 1998: 227 [redescription; comparison with M. cuneata Notman, 1920]: 246 [distribution]: 250, 252 [illustrations]. Pace 1999: 140 [comparison with M. coyhaiquensis Pace, 1999].

Type locality: "I. Isabela Sud, à $4 \mathrm{~km}$ de la côte, tamisage" (Pace 1985).

Distribution: Isabela Island (Galapagos Islands, Ecuador) (Pace 1985).

\section{Myllaena lynchi Fauvel, 1888}

Myllaena lynchi Fauvel 1888: 24 [citation as new species from $M$. parvicollis identified by Lynch (Lynch 1884: 99-100)]. Bernhauer \& Scheerpeltz 1926: 507 [in world catalog]. Blackwelder 1944: 153 [in checklist from Neotropical region].

Type locality: "Chacabuco" (Lynch 1884).

Distribution: Argentina (Lynch 1884).

\section{Myllaena mollis Sharp, 1883}

Myllaena mollis Sharp 1883: 285-286 [original description; comparison with $M$. intermedia Erichson, 1837, M. debilicornis Sharp, 1883 and M. fragilis Sharp, 1883]. Cameron 1922: 650 [comparison with $M$. celerrima Cameron, 1922]: 652 [comparison with $M$. granulata Cameron, 1922]. Bernhauer \& Scheerpeltz 1926: 508 [in world catalog]. Blackwelder 1944: 153 [in checklist from Neotropical region].

Type locality: "Guatemala, near the city" (Sharp 1883).

Distribution: Guatemala (Sharp 1883).

\section{Myllaena muelleri Pace, 1996}

Myllaena muelleri Pace 1996: 400 [original description; comparison with M. currax Notman, 1920]: 401 [illustrations]. Newton et al. 2005: 27 [in checklist from Colombia].

Type locality: "Kolumbien, Punta de Betin, Sta. Marta" (Pace 1996).

Distribution: Colombia (Pace 1996).

\section{Myllaena obscura Cameron, 1922}

Myllaena obscura Cameron 1922: 651-652 [original description; comparison with $M$. indefatigabilis Cameron, 1922]. Bernhauer \& Scheerpeltz 1926: 508 [in world catalog]. Blackwelder 1943: 535 [citation]: 579 [in checklist from West Indies]. Blackwelder 1944: 153 [in checklist from Neotropical region]. Type locality: "Haiti" (Cameron 1922). 
Distribution: Haiti (Cameron 1922).

\section{Myllaena obtusa Sharp, 1883}

Myllaena obtusa Sharp 1883: 286 [original description; comparison with M. glauca Aubé, 1850]. Bernhauer \& Scheerpeltz 1926: 508 [in world catalog]. Blackwelder 1944: 153 [in checklist from Neotropical region].

Type locality: "Guatemala, Torola 1000 feet" (Sharp 1883).

Distribution: Guatemala (Sharp 1883).

\section{Myllaena pallida Bernhauer, 1941}

Myllaena pallida Bernhauer 1941: 290 [original description]. Bernhauer 1951: 279-280 [original description; Note: republication of Bernhauer 1941 (Herman 2001)].

Type locality: "Südperu: Aina, 1400 m" (Bernhauer 1941).

Distribution: Peru (Bernhauer 1941).

Note: page of original description, type locality and distribution from Bernhauer 1941 by Dr Alfred F. Newton, FMNH (pers. comm.).

\section{Myllaena parvicollis Kraatz, 1859}

Myllaena parvicollis Kraatz 1859: 15-16 [original description; comparison with M. dubia (Gravenhorst, 1806)]. Fairmaire \& Germain 1861: 423-424 [redescription; comparison with M. dubia (Gravenhorst, 1806)]. Fauvel 1864: 124 [citation]. Bernhauer \& Scheerpeltz 1926: 508 [in world catalog]. Scheerpeltz 1934: 1529 [in world catalog]. Blackwelder 1944: 153 [in checklist from Neotropical region]. Lynch 1884: 99 [misidentification from $M$. lynchi Fauvel, 1888]. Coiffait \& Saiz 1967: 63 [characters; comparison with $M$. dilutipes Fairmaire \& Germain, 1861]: 61 [characters in key]. Scheerpeltz 1972: 27-28 [new records from Argentina]. Pace 1987b: 472 [comparison with M. araucaniensis Pace, 1987b]. Pace 1999: 121 [new records from Chile]. Type locality: type locality not given.

Distribution: Chile (Fairmaire \& Germain 1861); Argentina (Scheerpeltz 1972). Note: the record of M. parvicollis Kraatz, 1859 from Chacabuco, Argentina by Lynch (1884) is in fact $M$. lynchi Fauvel, 1888 (Fauvel 1888). But M. parvicollis was subsequently recorded from Rio Negro, Argentina by Scheerpeltz, 1972 (Dr Alfred F. Newton, FMNH, pers. comm.).

\section{Myllaena potawatomi Klimaszewski, 1982}

Myllaena potawatomi Klimaszewski 1982: 192-195 [original description, illustrated; in potawatomi species group; map distribution]: 184 [in checklist from Nearctic region]: 186 [geographic distribution]: 240 [illustration]: 191 [characters in key]. Pace 1987a: 188 [comparison with M. guadalupensis Pace, 1987a]. Klimaszewski \& Frank 1992: 398 [new records from USA]. Navarrete-Heredia et al. 2002: 191 [in checklist from Mexico]. Type locality: "USA: Wisconsin, Waukesha Co., Kettle Moraine St. F., 0.7 mi W Park HQ” (Klimaszewski 1982). 1982).

Distribution: USA; Mexico; Jamaica; Haiti (Klimaszewski

\section{Myllaena puthzi Pace, 1996}

Myllaena puthzi Pace 1996: 400 [original description; comparison with M. currax Notman, 1920]: 403 [illustrations]. Newton et al.
2005: 27 [in checklist from Colombia].

Type locality: "N Kolumbien, Nordwestl. Sierra Nevada de Sta. Marta, ca. 1000 m, nahe San Pedro de la Sierra" (Pace 1996).

Distribution: Colombia (Pace 1996).

\section{Myllaena robusta Sharp, 1883}

Myllaena robusta Sharp 1883: 287 [original description]. Bernhauer \& Scheerpeltz 1926: 508 [in world catalog]. Blackwelder 1944: 153 [in checklist from Neotropical region].

Type locality: "Guatemala, near the city" (Sharp 1883).

Distribution: Guatemala (Sharp 1883).

\section{Myllaena serrano Klimaszewski, 1982}

Myllaena serrano Klimaszewski 1982: 210 [original description]: 204 [map distribution (error: legend)]: 209, 240 [illustrations]. Navarrete-Heredia et al. 2002: 191 [in checklist from Mexico]. Type locality: "USA: California, San Bernardino Mts., nr 23661" (Klimaszewski 1982).

Distribution: USA; Mexico (Klimaszewski 1982).

Note: Blackwelder (1944) quoted Myllaena minuta (Gravenhorst, 1806) with doubtful distribution in the Neotropical region ("?Venezuela, U.S.A., Old World" in Blackwelder 1944, page 153). In this paper, we excluded $M$. minuta from the list of species occurring in the Neotropical region.

Acknowledgments. We wish to thank to Dr. Alfred F. Newton (FMNH) for valuable information about Myllaena species from the Neotropical region; Dr. Cibele S. Ribeiro-Costa (UFPR) and two anonymous reviewers for discussion and suggestions about this paper; Dr. Carla de Lima Bicho (UFPR) for providing the specimens of $M$. brasilienisis sp. nov..; the Biological Collection Network of Paraná (Taxon-line, UFPR) for the photographs; and the Conselho Nacional de Desenvolvimento Científico e Tecnológico (CNPq) for the Scholarships to the first author.

\section{REFERENCES}

Ahn, K. J \& J. S. Ashe. 2004. Phylogeny of the Myllaenini and related taxa (Coleoptera: Staphylinidae: Aleocharinae). Cladistics 20: 123-138.

Ashe, J. S. 2005. Phylogeny of the tachyporine group subfamilies and 'basal'lineages of the Aleocharinae (Coleoptera: Staphylinidae) based on larval and adult characteristics. Systematic Entomology 30: $3-37$.

Aubé, C. 1850. Description de quelques insectes coléoptères appartenant à l'Europe et à l'Algérie. Annales de la Société Entomologique de France 8: 299-346.

Bernhauer, M. 1941. Staphylinidae (Col.). Beiträge zur Fauna Perus 1: 277-293.

Bernhauer, M. 1951. Staphylinidae (Col.). Beiträge zur Fauna Perus 2: 267-282. [Note: reprinted from Bernhauer 1941].

Bernhauer, M. \& O. Scheerpeltz. 1926. Staphylinidae VI. In: S. Schenkling (ed.), Coleopterorum Catalogus 6: 499-988. Berlin: Junk.

Blackwelder, R. E. 1936. Morphology of the coleopterous family Staphylinidae. Smithsonian Miscellaneous Collections 94: $1-102$.

Blackwelder, R. E. 1943. Monograph of the West Indian beetles of the 
family Staphylinidae. United States National Museum Bulletin 182: i-viii + 1-658.

Blackwelder, R. E. 1944. Checklist of the coleopterous insects of Mexico, Central America, the West Indies, and South America. Part 1. United States National Museum Bulletin 185: xii + $1-188$.

Cameron, M. 1922. Descriptions of new species of Staphylinidae from the West Indies. Part II. The Annals and Magazine of Natural History 9: 633-652.

Casey, T. L. 1911. New American species of Aleocharinae and Myllaeninae. Memoirs on the Coleoptera 2. New Era Printing Co.: Lancaster, Pennsylvania, 245 pp.

Coiffait, H. \& F. Saiz. 1967. Aleocharidae du Chili. I. Tribus Oligotini, Myllaenini, Bolitocharini (Col. Staphylinoidea). Bulletin de la Société d' Histoire Naturelle de Toulouse 103: 51-98.

Erichson, W. F. 1837. Die Käfer der Mark Brandenburg 1, Berlin. 384 pp.

Fairmaire, L. \& P. Germain. 1861. Révision des Coléoptères du Chili. Annales de la Société Entomologique de France 1: 405-456.

Fauvel, A. 1864. Remarques critiques sur les Staphylinides décrits par Solier dans l'Historia de Chile de Gay. Annales de la Société Entomologique de France 4: 117-129.

Fauvel, A. 1888. Los estafilinos de Buenos Aires. Notes sur l'ouvrage de M. F. Lynch Arribalzaga. Revue d' Entomologie 7: 24-25.

Ganglbauer, L. 1895. Die Käfer von Mitteleuropa. Die Käfer der österreichisch-ungarischen Monarchie, Deutschlands, der Schweiz, sowie des französischen und italienischen Alpengebietes. 2. Familienreihe Staphylinoidea. Theil I. Staphylinidae, Pselaphidae. Wien: Carl Gerold's Sohn. 881 p.

Gravenhorst, J. L. 1806. Monographia Coleopterorum Micropterorum. Gotingae. $236 \mathrm{pp}$.

Herman, L. H. 2001. Catalog of the Staphylinidae (Insecta: Coleoptera) 1758 to the end of the second millennium, parts I-VII. Bulletin of the American Museum of Natural History 167: 1-4218.

Klimaszewski, J. 1982. Studies of Myllaenini (Coleoptera: Staphylinidae, Aleocharinae) 1. Systematics, phylogeny, and zoogeography of Nearctic Myllaena Erichson. The Canadian Entomologist 114: $181-242$.

Klimaszewski, J. \& J. H. Frank. 1992. New distributional data for Nearctic Myllaena Erichson (Coleoptera: Staphylinidae). Supplement 2. The Coleopterists Bulletin 46: 397-402.

Klimaszewski, J. \& F. Génier. 1986. New distribution and collection data for Nearctic Myllaena Erichson: Studies of Myllaenini (Coleoptera: Staphylinidae: Aleocharinae), supplement 1. The Coleopterists Bulletin 40: 33-36.

Klimaszewski, J. \& S. B. Peck. 1998. A review of aleocharine rove beetles from the Galápagos Islands, Ecuador (Coleoptera: Staphylinidae, Aleocharinae). Revue Suisse de Zoologie 105: 221-260.

Kraatz, G. 1853. Vier neue Myllaena. Stettiner Entomologische Zeitung 14: 373-374.

Kraatz, G. 1859. Zur kritischen Kenntniss der in Gay's Historia fisica y politica von Solier beschriebenen Staphylinen. Berliner Entomologische Zeitschrift 3: 1-16.
Lynch, F. A. 1884. Los estafilinos de Buenos Aires. Boletin de la Academia Nacional de Ciencias, Córdoba 7: 5-392.

Moore, I. \& E. F. Legner. 1975. A Catalogue of the Staphylinidae of America North of Mexico (Coleoptera). Special publication 3015, Division of Agricultural Sciences, University of California, $514 \mathrm{pp}$.

Navarrete-Heredia, J. L.; A. F. Newton; M. K. Thayer; J. S. Ashe \& D. S. Chandler. 2002. Guía ilustrada de los géneros de Staphylinidae (Coleoptera) de México - Illustrated Guide to the Genera of Staphylinidae (Coleoptera) of Mexico. México, D.F., Universidad de Guadalajara y CONABIO, xii +401 pp.

Newton, A. F. \& M. K. Thayer. 2005. Catalog of higher taxa of Staphyliniformia and genera and subgenera of Staphylinoidea [on line]. Chicago: Field Museum of Natural History [last updated 27 August 2005]. Available from URL:<www.fieldmuseum.org/peet_staph/db_1a.html> [accessed on 05 October 2007].

Newton, A. F.; C. G. Chacón \& D. S. Chandler. 2005. Checklist of the Staphylinidae (Coleoptera) of Colombia. Biota Colombiana 6: $1-72$.

Notman, H. 1920. Staphylinidae from Florida in the collection of the American Museum of Natural History, with descriptions of new genera and species. Bulletin of the American Museum of Natural History 42: 693-732.

Pace, R. 1985. Aleocharinae delle isole Galapagos (Coleoptera, Staphylinidae) (73. Contributo alla conoscenza delle Aleocharinae). Annales de la Societe Entomologique de France 21: 449456.

Pace, R. 1987a. Aleocharinae dell'isola della Guadalupa (Antille) (Coleoptera: Staphylinidae). Folia Entomologica Hungarica 48: $187-205$

Pace, R. 1987b. Aleocharinae del Cile (Coleoptera Staphylinidae) (97 Contributo alla conoscenza delle Aleocharinae). Redia 70: 459522 .

Pace, R. 1996. Aleocharinae from Colombia and Ecuador: Part 1 (Coleoptera, Staphylinidae). Aleocharinae della Colombia e dell'Ecuador: Parte 1 (Coleoptera, Staphylinidae). Revue Suisse de Zoologie 103: 395-437.

Pace R. 1997. Aleocharinae attere del North Carolina, Tennessee e Oregon (Coleoptera, Staphylinidae). Museo Regionale di Scienze Naturali Bollettino (Torino) 15: 101-110.

Pace, R. 1999. Aleocharinae del Cile (Coleoptera, Staphylinidae) (114o Contributo alla conoscenza delle Aleocharinae). Bollettino del Museo Civico di Storia Naturale di Verona 23: 119-210.

Scheerpeltz, O. 1934. Staphylinidae VIII. In: S. Schenkling (ed.), Coleopterorum Catalogus 6: 1501-1881. Berlin: Junk.

Scheerpeltz, O. 1972. Wissenschaftliche Ergebnisse der Studienreise von Gy. Topál nach Südwest-Argentinien (Coleoptera: Staphylinidae). Folia Entomologica Hungarica 25 (Supplement): 268 pp., pls. $1-5$.

Sharp, D. S. 1883. Staphylinidae. pp. 145-312. In: Biologia CentraliAmericana. Insecta. Coleoptera I (2). London: Taylor \& Francis. 